\title{
Kinetics on the Carboxylation of Cyclohexanone in Dimethyl Sulfoxide Solution Containing 1,8-Diazabicyclo $[5,4,0]$ undec-7-ene and Carbon Dioxide
}

\begin{abstract}
Masahiro Iwatani*, Kiyoshi Kudo*, Nobuyuki Sugita* and Yoshimasa Takezaki*
Carboxylation of cyclohexanone $(\mathbf{1})$ with carbon dioxide $\left(\mathrm{CO}_{2}\right)$ has been investigated in a dimethyl sulfoxide (DMSO) solution containing 1,8-diazabicyclo $[5,4,0]$ undec-7-ene (DBU). Effects of variables, such as concentration of 1 and $\mathrm{DBU}$, pressure of $\mathrm{CO}_{2}$ and temperature, on the rate of formation of DBU salts of cyclohexanone-2-carboxylic acid (2) have been examined kinetically. The kinetic investigation suggests that carboxylation begins with the formation of a complex between $\mathrm{DBU}$ and $\mathrm{CO}_{2}(1: 1)$ and that the transfer of $\mathrm{CO}_{2}$ from the complex to $\mathbf{1}$ to form $\mathbf{2}$ is the slow step. The rate is first order with respect to the concentration of $\mathbf{1}$ and DBU, but non-linear with respect to the pressure of $\mathrm{CO}_{2}$. The equilibrium constant of the formation of 2 (formulated as $\mathbf{1}+\mathrm{CO}_{2}+\mathrm{DBU} \rightleftharpoons \mathbf{2} \cdot \mathrm{DBU}$ ) in DMSO has been determined at various temperatures.
\end{abstract}

\section{Introduction}

The carboxylation of active hydrogen compounds, RH, with $\mathrm{CO}_{2}$ using alkali bases, BM, according to Eq. 1, has recently been reported in several papers $^{1) \sim 5)}$.

$$
\mathrm{RH}+\mathrm{CO}_{2}+\mathrm{BM} \rightarrow \mathrm{RCOOM}+\mathrm{BH}
$$

Of these, the alkali phenoxide reaction is typical, and the reaction mechanism has been investigated extensively. Two mechanisms for this reaction have been postulated.

It is well known that alkali phenoxide forms a stable complex with $\mathrm{CO}_{2}$. In the first mechanism, as represented by scheme $\mathrm{I}^{5}$, this complex is considered as an intermediate of $\mathrm{BM}$, alkali phenoxide, in the first reaction of the scheme as follows:

$$
\left.\begin{array}{l}
\mathrm{BM}+\mathrm{CO}_{2} \longrightarrow \mathrm{BM} \cdot \mathrm{CO}_{2} \\
\mathrm{BM} \cdot \mathrm{CO}_{2}+\mathrm{RH} \longrightarrow \mathrm{RCOOM}+\mathrm{BH}
\end{array}\right\} \quad \text { Scheme I }
$$

Similar mechanism has been proposed for carboxylation in the presence of $\mathrm{N}$-potassium pyrrolidone ${ }^{2}$ ) and for the formation of alkali alkyl carbonate by O-carboxylation of alcohol. ${ }^{6}$ )

The second mechanism is represented by the following scheme. ${ }^{\text {?) }}$

$$
\left.\begin{array}{l}
\mathrm{BM}+\mathrm{RH} \rightleftharpoons \mathrm{BH}+\mathrm{RM} \\
\mathrm{RM}+\mathrm{CO}_{2} \rightleftharpoons \mathrm{RCOOM}
\end{array}\right\} \quad \text { Scheme II }
$$

However, it has not been clarified whether BM. $\mathrm{CO}_{2}$ is formed first and then it reacts with $\mathrm{RH}$, (Scheme I), or RM is formed first and then it reacts with $\mathrm{CO}_{2}$ (Scheme II).

\footnotetext{
Received June 7, 1977.

* Institute for Chemical Research, Kyoto University (Gokanosho, Uji-shi, Kyoto 611)
}

Recently, DBU has shown to be an efficient carboxylating agent of active hydrogen compounds in a reaction such as: ${ }^{8)}$

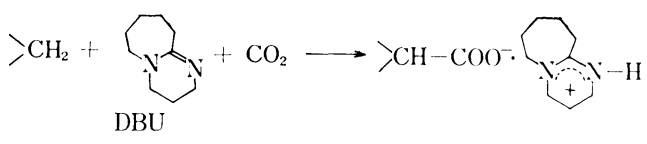

However, no results of kinetic study have been reported so far on this reaction. Thus, in order to delve deeply into the mechanism of this reaction, we have studied it from the kinetic viewpoint. This paper presents the results and discussion on the mechanism of the carboxylation of $\mathbf{1}$ with $\mathrm{CO}_{2}$ in a DMSO solution containing DBU.

\section{Results}

\subsection{Preliminary Investigations}

The results of carboxylation of $\mathbf{1}$ under various conditions are shown in Table 1. The acid 2, decomposes to $\mathrm{CO}_{2}$ and $\mathbf{1}$ readily as would be expected of a keto acid; therefore, in order to restrain this decomposition, same adjustment of reaction temperature and pressure of $\mathrm{CO}_{2}$ becomes important.

From these results, we can see that at higher temperatures decomposition takes place to a remarkable degree even under relatively high pressure(Run 1), and that at lower temperatures, the decomposition can be suppressed sufficiently(Run. 8). It was noted that carboxylation of $\mathbf{1}$ apparently had completed within about three hours under normal conditions, and the yield did not change for further 
Table 1 Preliminary Survey of Reaction Condition

\begin{tabular}{|c|c|c|c|c|c|c|c|c|}
\hline \multirow{2}{*}{ Runs } & \multicolumn{6}{|c|}{ Reaction Conditions } & \multicolumn{2}{|c|}{ Results } \\
\hline & $\begin{array}{c}1 \times 10^{2} \\
(\mathrm{~mol})\end{array}$ & $\begin{array}{c}\text { DBUa }) \times 10^{2} \\
(\mathrm{~mol})\end{array}$ & $\begin{array}{l}\mathrm{DMSO}^{\mathrm{b})} \\
\quad(\mathrm{m} l)\end{array}$ & $\begin{array}{l}P_{\mathrm{CO}_{2}} \\
(\text { atm })\end{array}$ & $\begin{array}{l}\text { Temp. } \\
\left({ }^{\circ} \mathrm{C}\right)\end{array}$ & $\begin{array}{c}\text { Time } \\
(\mathrm{hr})\end{array}$ & $\begin{array}{l}\text { Yield of } \mathbf{2}^{\mathrm{c})} \\
\quad(\mathrm{mol} \%)\end{array}$ & $\begin{array}{c}\mathbf{1}^{\mathrm{d})} \\
(\mathrm{mol} \%)\end{array}$ \\
\hline 1 & 1.38 & 2.74 & 10 & 90 & 120 & 3 & 12 & - \\
\hline 2 & 1.38 & 2.74 & 10 & 125 & 100 & 3 & 44 & - \\
\hline 3 & 1.38 & 2.74 & 10 & 95 & 80 & 3 & 51 & $\ldots$ \\
\hline 4 & 1.38 & 2.74 & 10 & 70 & 60 & 3 & 57 & - \\
\hline 5 & 1.38 & 2.74 & 10 & 60 & 60 & 28 & 60 & 37 \\
\hline 6 & 6.90 & 13.70 & 100 & 1.5 & 45 & $1 *$ & $26 * *$ & 70 \\
\hline 7 & 6.90 & 13.70 & 100 & 3.0 & 25 & $3^{*}$ & $44 * *$ & 54 \\
\hline 8 & 6.90 & 13.70 & 100 & 10.0 & 24 & $0.5 *$ & $54 * *$ & 43 \\
\hline
\end{tabular}

a) 1,8-diazabicyclo [5, 4, 0] undec-7-ene. b) Dimethyl sulfoxide. c) Cyclohexanone-2-carboxylic acid-DBU salt (2) produced on charged cyclohexanone (1). d) Residual 1 based on charged 1.

* Time required to nearly reach equilibrium.

** Yield at equilibrium.

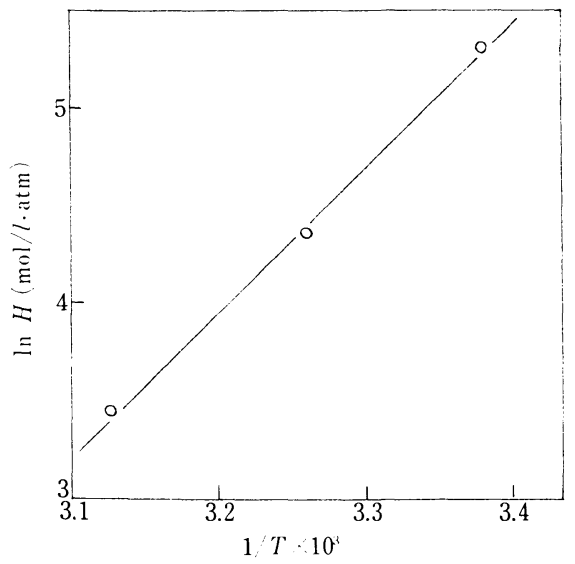

Fig. 1 Relationship between $1 / T$ and $\ln H$

28 hours(Run. 4, 5). The increased formation of $\mathbf{2}$ was observed by further addition of $\mathbf{1}$ to the reaction mixture in equilibrium. Also, the sum of the amounts of $\mathbf{2}$ produced and the remaining $\mathbf{1}$ accounted for over $96 \%$ of $\mathbf{1}$ charged.

These observations seem to suggest that the reaction is in equilibrium (see later).

The product was confirmed by elementary analysis to be a DBU salt of 2, combining in 1:1 molar ratio.

The solubility of $\mathrm{CO}_{2}$ in DMSO was measured in the range from 5 to $25 \mathrm{~atm}$. Values of Henry's constant $(H)$ determined from the slope of each of the linear plots are summarized in Table 5. The temperature coefficient of $H$ was obtained as -4 $\mathrm{kcal} / \mathrm{mol}$ (exothermic) (Fig. 1).

The effect of stirring speed on the initial rate $\left(V_{0}\right)$ of carboxylation was examined to eliminate the effect of diffusion of $\mathrm{CO}_{2}$ on the reaction. The initial rate was independent of stirring speeds above $800 \mathrm{rpm}$ as shown in Table 2. Therefore, the kinetic experiments were carried out at above 800 rpm.
Table 2 Effect of Stirring Speed

\begin{tabular}{c|c}
\hline Stirring Speed $(\mathrm{rpm})$ & $V_{\mathbf{0}} \times 10^{3}(\mathrm{~mol} / l \cdot \mathrm{min})$ \\
\hline 400 & 2.90 \\
800 & 4.42 \\
1,300 & 4.40 \\
\hline
\end{tabular}

Conditions : $\mathbf{1}=0.573 \mathrm{~mol} / l, \quad \mathrm{DBU}=0.573 \mathrm{~mol} / l$, $P_{\mathrm{CO}_{2}}=1.5 \mathrm{~atm}$ at $24^{\circ} \mathrm{C}$.

\subsection{Kinetic Results}

The following variables were examined kinetically: initial concentrations of $\mathbf{1}$ and DBU, pressure of $\mathrm{CO}_{2}$ and temperature. Of these, two time-yield profiles are shown in Figs. 2 and $\mathbf{3}$ as typical examples. As is shown in Fig. 2, the yield of $\mathbf{2}$ increased with increase in pressure; for about two hours and thereafter it leveled off.

The dependence of the initial production rate of 2 on the pressure of $\mathrm{CO}_{2}$ is shown in Fig. 4. The initial rate $\left(V_{0}\right)$ increased nonlinearly with pressure. On the other hand, the initial rate increased almost linearly with the initial concentrations of $\mathbf{1}$ and DBU. These results suggest that the rate is of first order with respect to $\mathbf{1}$ and DBU. The effect of reaction temperature is shown in Fig. 3. The initial rate increased with rising temperature; however, the final conversion of $\mathbf{1}$ to $\mathbf{2}$ decreased with rise in temperature.

We also observed a gradual formation of a stable white precipitate when dry $\mathrm{CO}_{2}$ was introduced into DBU under atmospheric pressure at room temperature. Presumably, similar to the reaction of phenoxide state above, this reaction may be expressed as Eq. 3.

$$
\mathrm{DBU}+\mathrm{CO}_{2} \rightleftharpoons\left[\mathrm{DBU} \cdot \mathrm{CO}_{2}\right]
$$

By elementary analysis the product was confirmed to be 3, an adduct of $\mathrm{CO}_{2}$ and $\mathrm{DBU}$ in $1: 1$ molar ratio. 


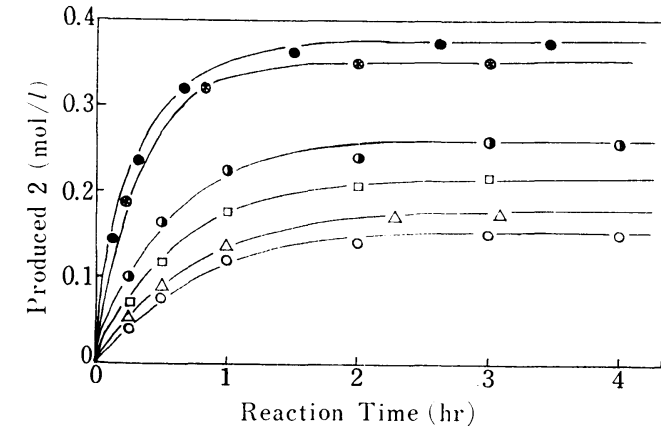

$24 \sim 26^{\circ} \mathrm{C}, \quad \mathbf{1}=0.573 \mathrm{~mol} / l, \quad \mathrm{DBU}=0.573 \mathrm{~mol} / l$ $\mathrm{CO}_{2}$ pressure $(\mathrm{atm}): 12(\bigcirc), 10(\circledast), 3(\mathbf{\top})$, $2(\square), 1.5(\triangle), 1.2(\bigcirc)$

Fig. 2 Effect of $\mathrm{CO}_{2}$ Pressure

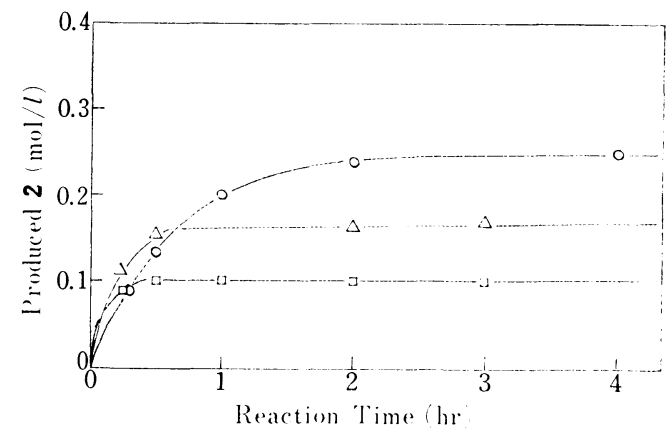

$\mathrm{CO}_{2}=1.5 \mathrm{~atm}, \mathbf{1}=0.523 \mathrm{~mol} / l, \mathrm{DBU}=1.055 \mathrm{~mol} / l$, Reaction temp. $\left({ }^{\circ} \mathrm{C}\right): 26(\bigcirc), 35(\triangle), 45(\square)$.

Fig. 3 Effect of Reaction Temperature

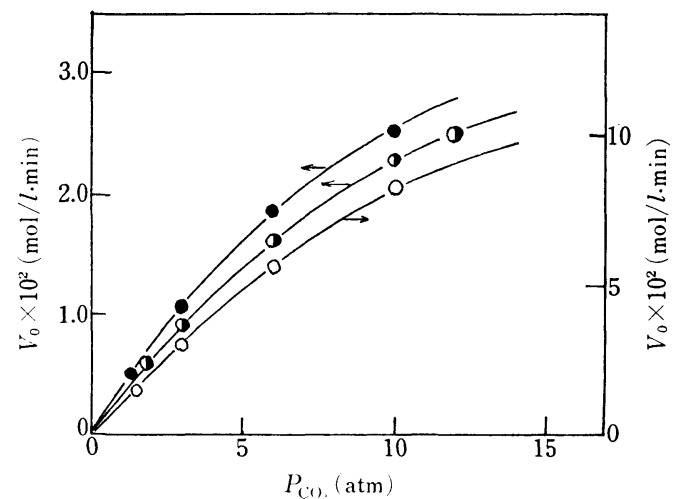

$\mathbf{1}=0.527 \mathrm{~mol} / l, \quad \mathrm{DBU}=1.055 \mathrm{~mol} / l,(0.573 \mathrm{~mol} / l$ at $24^{\circ} \mathrm{C}$ )

Reaction temp. $\left({ }^{\circ} \mathrm{C}\right): 20(\mathbf{O}), 24(\mathrm{O}), 35(\bigcirc)$.

Fig. 4 Relation between $\mathrm{CO}_{2}$ Pressure and Initial Rate $\left(V_{0}\right)$

In alkali phenoxide- $\mathrm{CO}_{2}$ complex, where the $\mathrm{CO}_{2}$ is in the bending form, gives rise to an IR absorption at near $1,600 \mathrm{~cm}^{-1}$ due to the functional carbonyl' (2),9). The IR absorption spectrum of complex 3 in nujol or DMSO shows a new band at $1,640 \mathrm{~cm}^{-1}$. This band seems to indicate a complex formation between $\mathrm{CO}_{2}$ and $\mathrm{DBU}$.

\subsection{Equilibrium Study}

The results of above investigation suggest that
Table 3 Equilibrium Composition and $K^{\prime}$

\begin{tabular}{|c|c|c|c|c|c|c|}
\hline \multicolumn{4}{|c|}{ Conditions ${ }^{\mathrm{a}}$ ) } & \multicolumn{3}{|c|}{ Results $^{b)}$} \\
\hline $\begin{array}{r}\text { Temp. } \\
\left({ }^{\circ} \mathrm{C}\right)\end{array}$ & $\begin{array}{c}c_{0} \\
(\mathrm{~mol} / l)\end{array}$ & $\begin{array}{c}d_{\mathbf{0}} \\
(\mathrm{mol} / l)\end{array}$ & $\begin{array}{c}P_{\mathrm{CO}_{2}} \\
(\mathrm{~atm})\end{array}$ & $\begin{array}{c}x_{\mathrm{eq}} \\
(\mathrm{mol} / l)\end{array}$ & $\begin{array}{c}\mathbf{B} \\
(l / \mathrm{mol})\end{array}$ & $\begin{array}{c}K^{\prime} \\
\left(l^{2} /\right. \\
\left.\mathrm{mol}^{2}\right)\end{array}$ \\
\hline 20 & 0.527 & 1.055 & $\left\{\begin{array}{c}1.5 \\
3 \\
10\end{array}\right.$ & $\begin{array}{l}0.311 \\
0.381 \\
0.466\end{array}$ & $\begin{array}{r}1.935 \\
3.872 \\
12.970\end{array}$ & $\begin{array}{l}24.3 \\
24.5 \\
24.4\end{array}$ \\
\hline 24 & 0.573 & 0.573 & $\left\{\begin{array}{r}2 \\
3 \\
12\end{array}\right.$ & $\begin{array}{l}0.215 \\
0.256 \\
0.371\end{array}$ & $\begin{array}{l}1.678 \\
2.548 \\
9.689\end{array}$ & $\begin{array}{l}17.5 \\
17.7 \\
17.6\end{array}$ \\
\hline 35 & 0.527 & 1.055 & $\left\{\begin{array}{l}1.5 \\
3\end{array}\right.$ & $\begin{array}{l}0.167 \\
0.245\end{array}$ & $\begin{array}{l}0.522 \\
1.073\end{array}$ & $\begin{array}{l}9.7 \\
9.5\end{array}$ \\
\hline 20 & 0.081 & 0.280 & $\begin{array}{l}(10 \\
1.5\end{array}$ & $\begin{array}{l}0.373 \\
0.142\end{array}$ & $\begin{array}{l}4.162 \\
1.957\end{array}$ & $\begin{array}{c}9.6 \\
24.4^{\mathrm{c})}\end{array}$ \\
\hline
\end{tabular}

a) $c_{0}$ and $d_{0}$ : Initial conc. of cyclohexanone and DBU.

b) $x_{\text {eq }}$ : Equilibrium conc. of cyclohexanone-2-carboxylic acid. DBU salt, $\mathrm{B}=x_{\mathrm{eq}} /\left(c_{0}-x_{\mathrm{eq}}\right)\left(d_{0}-x_{\mathrm{eq}}\right)$.

c) cyclohexanone-2-carboxylic acid. $\mathrm{DBU}$ salt $(0.288$ $\mathrm{mol} / l)$ was added.

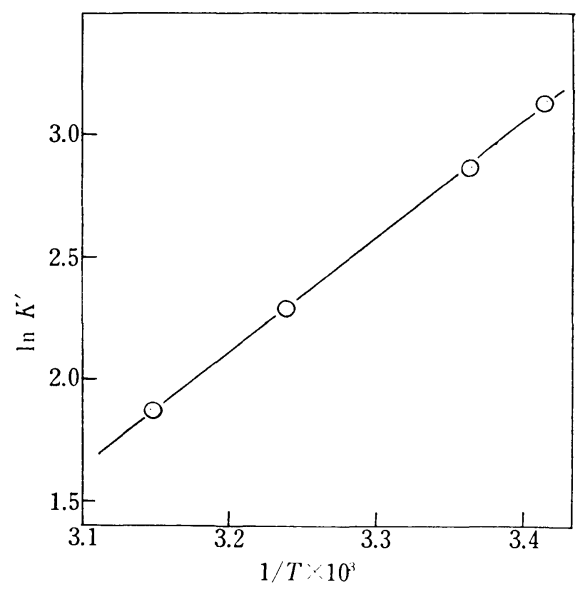

Fig. 5 Temperature Effect on Equilibrium Constants

equilibrium exists between the product and reactants.

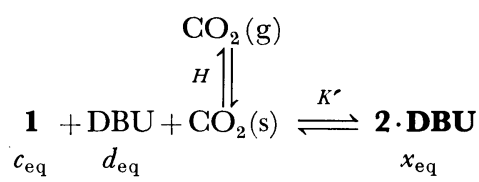

The overall equilibrium constant, $K^{\prime}$, can then be expressed as:

$$
K^{\prime}=\frac{x_{\mathrm{eq}}}{c_{\mathrm{eq}} \cdot d_{\mathrm{eq}} \cdot H P}
$$

where, $H$ is the Henry's constant for $\mathrm{CO}_{2}$ dissolved in DMSO, $P$ is the pressure of $\mathrm{CO}_{2}$, and $c_{\mathrm{eq}}, d_{\mathrm{eq}}$ and $x_{\mathrm{eq}}$ are the concentrations of $\mathbf{1}, \mathrm{DBU}$ and $\mathbf{2}$. DBU at equilibrium, respectively. The values of $K^{\prime}$ can be calculated from Eq. 5 by measuring the concentrations of $\mathbf{1}$ and $\mathbf{2}$ in equilibrium under various conditions and the resulting values are summarized in Table 3. Also, the values of $K^{\prime}$ obtained by decomposition of proper amount of $\mathbf{2} \cdot \mathbf{D B U}$ at $20^{\circ} \mathrm{C}$ (see the last line of Table 3 ) agree with the value obtained from forward reaction. As shown 
in Table 3, the values of $K^{\prime}$ remain unchanged for all levels of $\mathbf{1}$ and DBU concentrations and $\mathrm{CO}_{2}$ pressure. Note that the increase in temperature decreases the value $K^{\prime}$. From the plot of $\ln K^{\prime}$ vs. $1 / T$ (Fig. 5), the heat of overall reaction is found to be $-10 \mathrm{kcal} / \mathrm{mol}$ (exothermic).

\section{Discussion}

As has already mentioned, DBU forms an adduct complex with $\mathrm{CO}_{2}$. When a mixture of isolated $3(11.1 \mathrm{mmol}), 1(12.4 \mathrm{mmol})$, and DMSO $(10 \mathrm{ml})$ was stirred without $\mathrm{CO}_{2}$ at room temperature for one hour, 2 was obtained in $35.6 \%$ yield based on 3, while, 1 did not react with $\mathrm{CO}_{2}$ in the absence of $\mathrm{DBU}$ at room temperature. It must be reasonable to assume that the initial product formed in the reaction (Eq. 2) is acomplex (3) which reacts with $\mathbf{1}$ to give 2, viz.,

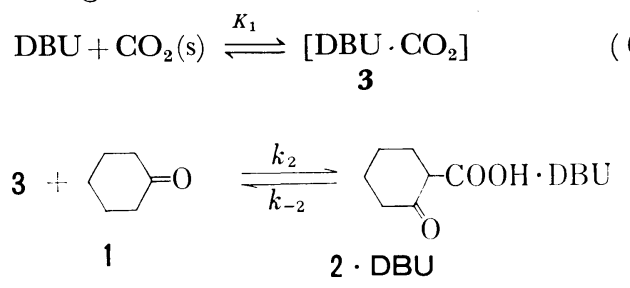
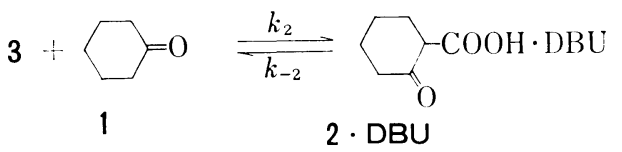

where the formation of complex $\mathbf{3}$ attains equilibrium quickly and the subsequent reaction of $\mathbf{1}$ with complex $\mathbf{3}$ is the rate-determining step. Thus, the rate of $\mathbf{2} \cdot \mathbf{D B U}$ formation is derived as follow. The material balance for DBU and $\mathbf{1}$ can be given by,

$$
\begin{aligned}
& c_{0}=c+x \\
& d_{0}=d+y+x
\end{aligned}
$$

where $c_{0}, d_{0}, c$ and $d$ are the concentrations of $\mathbf{1}$ and DBU charged and the remaining $\mathbf{1}$ and DBU, and $y$ and $x$ are the concentrations of complex $\mathbf{3}$ and $\mathbf{2} \cdot \mathbf{D B U}$ produced, respectively.

Eq. 6 can be given by,

$$
K_{1}=\frac{y}{d \cdot H P}
$$

and the concentration of complex $3, y$, can be obtained as

$$
y=\frac{K_{1} H P}{1+K_{1} H P}\left(d_{0}-x\right)
$$

The rate equation of producing $2 \cdot \mathbf{D B U}$ can be expressed as in Eq. 12:

$$
\begin{aligned}
\frac{\mathrm{d} x}{\mathrm{~d} t} & =k_{2} y\left(c_{0}-x\right)-k_{-2} x \\
& =\frac{k_{2} K_{1} H P}{1+K_{1} H P}\left(d_{0}-x\right)\left(c_{0}-x\right)-k_{-2} x
\end{aligned}
$$

Equation 12 accounts for the facts that the initial rate is not linear with the pressure of $\mathrm{CO}_{2}$ as shown
Fig. 4, and that the rate is of first-order with respect to initial concentrations of $\mathbf{1}$ and DBU.

If $x_{\mathrm{eq}}$ is the concentration of $\mathbf{2} \cdot \mathbf{D B U}$ produced at equilibrium, when the net rate of the reaction is zero,

where

$$
R\left(c_{0}-x_{\mathrm{eq}}\right)\left(d_{0}-x_{\mathrm{eq}}\right)=k_{-2} x_{\mathrm{eq}}
$$

$$
R=\frac{k_{2} K_{1} H P}{1+K_{1} H P}
$$

Substitution of this expression in Eq. 12 gives rise to Eq. 15

$$
\begin{aligned}
\frac{\mathrm{d} x}{\mathrm{~d} t} & =R\left[x^{2}-\left(c_{0}+d_{0}\right)+\frac{1}{x_{\mathrm{eq}}}\left(c_{0}-x_{\mathrm{eq}}\right)\left(d_{0}-x_{\mathrm{eq}}\right) x\right. \\
& \left.+c_{0} d_{0}\right]
\end{aligned}
$$

Integration of Fig. 15, using $x=0$ at $t=0$, gives:

$$
\mathrm{Rt}=\frac{1}{\sqrt{A}} \ln \frac{x_{\mathrm{eq}}-\left(\frac{S-\sqrt{A}}{S+\sqrt{A}}\right) x}{x_{\mathrm{eq}}-x}
$$

where

$$
\begin{aligned}
& S=\left(c_{0}+d_{0}\right)+\frac{1}{x_{\text {eq }}}\left(c_{0}-x_{\mathrm{eq}}\right)\left(d_{0}-x_{\mathrm{eq}}\right) \\
& A=S^{2}-4 c_{0} d_{0}
\end{aligned}
$$

Equation 16 is compared with the observed kinetic results which are found to be in line with correlation of Eq. 16 as shown in Figs. 6 and 7. The values of $R$ can be determined from the slopes of the plots, and they are given in Table 4. $R$ should be independent of the concentration of $\mathbf{1}$ and DBU, and this is actually the case (Table 4). If Eq. 14 is transformed into Eq. 17, the reciprocal of $R$ should increase linearly with increasing reciprocal of $P$.

$$
\frac{1}{R}=\frac{1}{k_{2} K_{1}} \cdot \frac{1}{H P}+\frac{1}{k_{2}}
$$

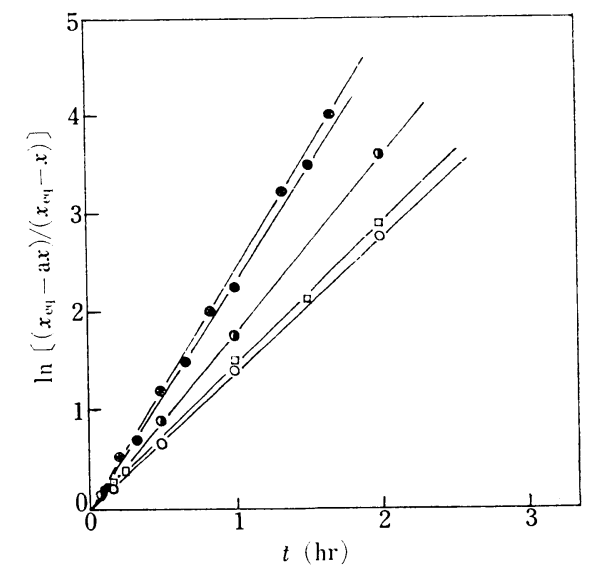

$$
\begin{aligned}
& \mathrm{a}=(S-\sqrt{A}) /(S+\sqrt{A}) \\
& \mathrm{CO}_{2} \text { pressure (atm) }: 12(\bigcirc), 10(\circledast), 3(\circlearrowleft), 2(\square), \\
& \quad 1.2(\bigcirc) .
\end{aligned}
$$

Fig. 6 Relationship between $t$ and $\left.\left.\ln \left[x_{\mathrm{eq}}-\mathrm{ax}\right) / x_{\mathrm{eq}}-x\right)\right]$ $\left(\mathrm{CO}_{2}\right.$ pressure effect at $\left.24^{\circ} \mathrm{C}\right)$ 
Table $4 \quad R$ Value from Integration of Eq. 16

\begin{tabular}{|c|c|c|c|c|c|c|c|c|}
\hline & \multicolumn{4}{|c|}{ Conditons } & \multicolumn{4}{|c|}{ Results } \\
\hline & $\begin{array}{l}\text { Temp. } \\
\left({ }^{\circ} \mathbf{C}\right)\end{array}$ & $\begin{array}{c}c_{0} \\
(\mathrm{~mol} / l)\end{array}$ & $\begin{array}{c}d_{\mathbf{0}} \\
(\mathrm{mol} / l)\end{array}$ & $\begin{array}{l}P_{\mathrm{CO}_{2}} \\
(\mathrm{~atm})\end{array}$ & $\begin{array}{c}x_{\mathrm{eq}} \\
(\mathrm{mol} / l)\end{array}$ & $\underset{(\mathrm{mol} / l)}{\sqrt{A}}$ & $\begin{array}{r}R \cdot V \bar{A} \\
\times 10^{2} \\
\left(\min ^{-1}\right) \\
\end{array}$ & $\begin{array}{c}R^{\mathrm{a})} \times 10^{2} \\
(l / \mathrm{mol} \cdot \mathrm{min})\end{array}$ \\
\hline & & & & 1.5 & 0.311 & 1.48 & 1.46 & 0.99 \\
\hline & 20 & 0.527 & 1.055 & 3 & 0.381 & 1.07 & 1.93 & 1.80 \\
\hline & & & & 10 & 0.466 & 0.59 & 2.6 & 4.42 \\
\hline & & & & 2 & 0.215 & 1.31 & 2.56 & 1.95 \\
\hline$P_{\mathrm{CO}_{2}} \&$ Temp. & 24 & 0573 & 0573 & 3 & 0.256 & 1.03 & 3.23 & 3.13 \\
\hline Effect & 24 & 0.013 & $0.5 / 3$ & 10 & 0.365 & 0.58 & 3.96 & 6.83 \\
\hline & & & & 12 & 0.380 & 0.50 & 3.74 & 7.48 \\
\hline & 25 & & & 1.5 & 0.167 & 3.16 & 7.52 & 2.38 \\
\hline & 35 & 0.527 & 1.055 & $\left\{\begin{array}{r}3 \\
10\end{array}\right.$ & $\begin{array}{l}0.245 \\
0.373\end{array}$ & 2.02 & $\begin{array}{r}9.10 \\
15.75\end{array}$ & $\begin{array}{r}4.55 \\
14.30\end{array}$ \\
\hline & & 0.201 & 1.874 & & 0.135 & 2.66 & 3.75 & 1.41 \\
\hline & & 0.330 & 1.848 & & 0.215 & 2.62 & 3.73 & 1.42 \\
\hline$c_{0} \& d_{0}$ Effect & 25 & 0.456 & 1.823 & & 0.294 & 2.53 & 3.60 & 1.42 \\
\hline & & 0.598 & 0.299 & 1.5 & 0.114 & 1.45 & 2.12 & 1.42 \\
\hline & & 0.527 & 1.055 & & 0.250 & 1.97 & 2.82 & 1.43 \\
\hline & 45 & 0.527 & 1.055 & & 0.105 & 5.00 & 21.60 & 4.32 \\
\hline
\end{tabular}

a) $R=k_{2} K_{1} H P /\left(1+K_{1} H P\right)$

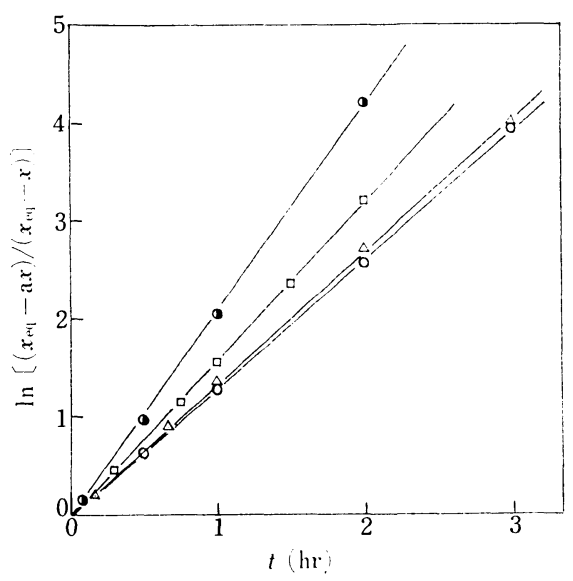

$\mathrm{a}=(S-\sqrt{A}) /(S+\sqrt{A})$

DBU concn. $(\mathrm{mol} / l): 1.823(\mathrm{)}), 1.055(\square), 0.573$ $(\triangle), 0.299(\bigcirc)$.

Fig. 7 Relationship between $t$ and $\ln \left[\left(x_{\mathrm{eq}}-a x\right) /\left(x_{\mathrm{eq}}-x\right)\right]$ (DBU concentration effect)

Thus, the plot of $1 / R$ against $1 / H P$ should give a slope of $1 / k_{2} K_{1}$ and an intercept of $1 / k_{2}$. The kinetic results are satisfied by Eq. 17 as shown in Fig. 8.

These studies suggest that the mechanism proposed above (analogous to Scheme I) sufficiently satisfies the kinetic results.

The values of $k_{2}$ and $K_{1}$ can be determined from the linear plots in Fig. 8 by means of Eq. 17. Also, the values of $k_{-2}$ can be estimated from $K^{\prime}=K_{1} k_{2} / k_{-2}$. The constants obtained are summarized in Table 5.

The temperature coefficients of $K_{1}$ and $k_{2}$ from the slopes in Fig. 9 were found to be $-4 \mathrm{kcal} / \mathrm{mol}$ (exothermic) and $22 \mathrm{kcal} / \mathrm{mol}$, respectively.

Though the effect of solvents on the reactivity of complex $\mathbf{3}$ was not investigated systematically, when such nonpolor solvents as benzene and cyclohexane, which dissolve $\mathbf{2} \cdot \mathbf{D B U}$ and complex $\mathbf{3}$ very

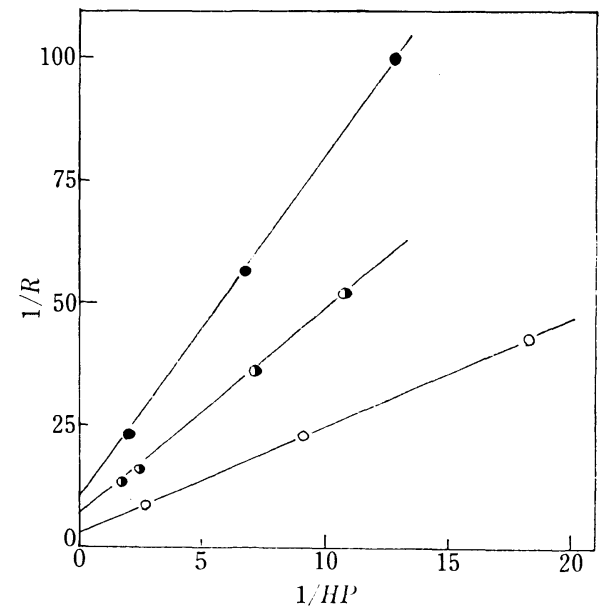

Reaction temp. $\left({ }^{\circ} \mathrm{C}\right): 35(\bigcirc), 24(\mathbf{O}), 20(\bigcirc)$

Fig. 8 Relation between $1 / R$ and $1 / H P$

Table 5 Rate and Equilibrium Constants

\begin{tabular}{cccccc}
\hline $\begin{array}{c}\text { Temp. } \\
\left({ }^{\circ} \mathrm{G}\right)\end{array}$ & $\begin{array}{c}H \\
(\mathrm{~mol} / l . \\
\mathrm{atm})\end{array}$ & $\begin{array}{r}k_{2} \\
(l / \mathrm{mol} . \\
\mathrm{min})\end{array}$ & $\begin{array}{c}k_{-2} \\
(l / \mathrm{min})\end{array}$ & $\begin{array}{c}K_{1} \\
(l / \mathrm{mol})\end{array}$ & $\begin{array}{c}K^{\prime} \\
\left(l \mathbf{2} / \mathrm{mol}^{2}\right)\end{array}$ \\
\hline 20 & 0.053 & 0.105 & 0.006 & 1.39 & 24.4 \\
24 & 0.048 & 0.178 & 0.013 & 1.25 & 17.6 \\
35 & 0.036 & 0.625 & 0.053 & 0.83 & 9.7 \\
\hline
\end{tabular}

slightly, were used, the carboxylation product in very low yields was obtained. In methyl alcohol solvent, yields were very low because of the considerable quantities of alkyl carbonate formed.

We can formulate another scheme,

$$
\begin{aligned}
& \mathbf{1}+\mathrm{DBU} \stackrel{K_{3}}{\rightleftharpoons}[\mathbf{1} \cdot \mathbf{D B U}] \\
& {[\mathbf{1} \cdot \mathbf{D B U}]+\mathrm{CO}_{2}(\mathrm{~s}) \stackrel{k_{4}}{\rightleftharpoons} \mathbf{2} \cdot \mathbf{D B U}}
\end{aligned}
$$

This mechanism is analogous to Scheme II, and it can be described as DBU in the solution reacting with 1 rather than with $\mathrm{CO}_{2}$ to form a complex 1.DBU. Reaction 18 would, therefore, compete 


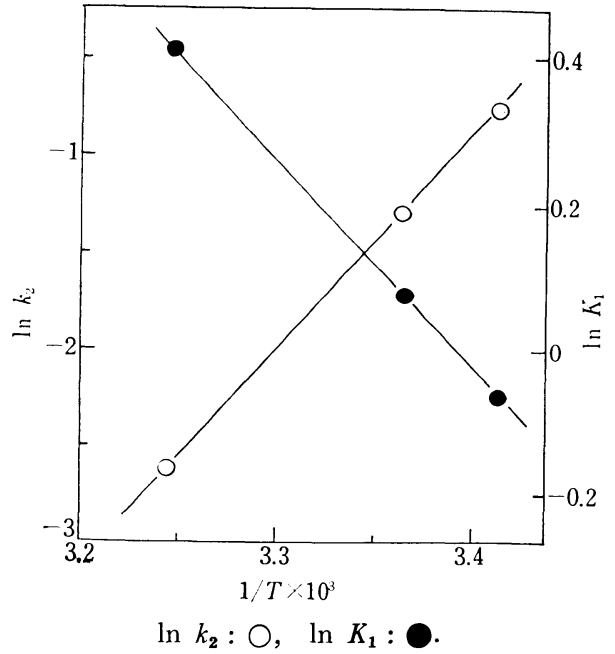

Fig. 9 Plots of $\ln k_{2}$ and $\ln K_{1}$ against $1 / T$

with reaction 6 . The extent of reaction 18 should be dependent on the acidity of $\mathbf{1}$. Because the acidity of $\mathrm{CO}_{2}\left(\mathrm{p} K_{a}=3.7\right)$ is higher than that of $\mathbf{1}\left(\mathrm{p} K_{\mathrm{a}}<15\right)^{29}$; the concentration of complex $\mathbf{1} \cdot \mathbf{D B U}$ is expected to be very small in a solution containing excess $\mathrm{CO}_{2}$.

Also, the rate equation derived from the scheme (Eqs. 18 and 19) is given by Eq. 20 in a similar way to that given above,

$$
\frac{\mathrm{d} x}{\mathrm{~d} t}=k_{4} \frac{\left(c_{0}-x\right)\left(d_{0}-x\right) H P}{\left(c_{0}+d_{0}+\frac{1}{K_{3}}\right)-2 x}-k_{-4} x
$$

The mechanism shown by Eq. 20, which is firstorder with respect to the pressure of $\mathrm{CO}_{2}$, can be excluded kinetically because the observed initial rate is not linear with respect to $\mathrm{CO}_{2}$ pressure as shown in Fig. 4.

\section{Experimental}

\subsection{Materials}

Reagents such as DBU, $\mathrm{CO}_{2}, \mathbf{1}$ and DMSO were commercially obtained and $\mathbf{1}$ and DMSO were purified by distillation

\subsection{Procedure of Kinetic Measurements}

Reactions were generally carried out in a stainless-steel autoclave (ca. $250 \mathrm{ml}$ ) equipped with a magnetic stirrer and a sampling line.

After charging the autoclave with DBU (0.065 $0.263 \mathrm{~mol}), 1(0.019 \sim 0.069 \mathrm{~mol})$ and DMSO (100 $\mathrm{m} l$ ), it was purged with nitrogen gas. The autoclave was then brought to the desired temperature (20 $\left.45^{\circ} \mathrm{C}\right)$. Immediately after $\mathrm{CO}_{2}$ had attained the desired reaction pressure $(1 \sim 15 \mathrm{~atm})$, stirring $(1,3$ $00 \sim 1,400 \mathrm{rpm}$ ) was started, and this time of starting was taken as zero reaction time. Stirring was stopped from time to time and a sample (ca. $1 \mathrm{ml}$ ) was withdrawn through the sampling line into a trap within $30 \mathrm{sec}$. The pressure of the autoclave was kept constant during the reaction by supplying fresh $\mathrm{CO}_{2}$ from the reservoir while the reaction temperature was maintained within $\pm 1{ }^{\circ} \mathrm{C}$.

All the initial rates were determined from the experimental equation, $y=\mathrm{a} t^{2}+\mathrm{b} t$, where $y=\mathbf{2}$ $(\mathrm{mol} / l)$ produced; $t=$ time $(\min ) ; \mathrm{a}, \mathrm{b}=$ constants. And the initial rate, $V_{0} \equiv(\mathrm{d} y / \mathrm{d} t)_{0}=\mathrm{b} \quad(\mathrm{mol} / l-\mathrm{min})$.

\subsection{Analysis}

The aqueous solution, obtained by pouring the products into ice-water containing a DBU salt of $\mathbf{2}$ is converted into free acid by passing through a column of cation exchanger (Amberlite IR-120B), and titrated with a $0.1 N-\mathrm{NaOH}$ aqueous solution to determine the amount of acid 2 .

\subsection{Identification of Products and Complex 3}

The resulting mixture of reaction was diluted with ice water and extracted with ether. The residual aqueous layer was then acidified with $\mathrm{HCl}$ while being cooled with an ice bath, and it was extracted again with ether. The ethereal extract was dried over $\mathrm{Na}_{2} \mathrm{SO}_{4}$, evaporated to dryness by rotary evaporation in vacuo at room temperature to give a white solid. The solid thus obtained was esterified with an ethereal solution of diazomethane and it was identical with the authentic methyl cyclohexanone-2-carboxylate as shown by gas chromatography (Apiezon Grease L 10\%, 140 $\mathrm{C}$ ). The only single acid product identified as $\mathbf{2}$ was found. And, the white material was confirmed by elementary analysis to be a salt of $\mathbf{2}$ consisting of DBU and 2 in 1:1 molar ratio according to Eq. 2. Found: $\mathrm{C}, 64.4 ; \mathrm{H}, 8.8 ; \mathrm{N}, 9.7 \%$. Calculated as $\mathrm{C}_{\mathbf{1 6}} \mathrm{H}_{26}{ }^{-}$ $\mathrm{N}_{2} \mathrm{O}_{3}: \mathrm{C}, 65.5 ; \mathrm{H}, 8.5 ; \mathrm{N}, 9.6 \%$. The DBU $\cdot \mathrm{CO}_{2}$ complex was prepared as follows: DBU $(25 \mathrm{ml}$, $0.167 \mathrm{~mol}$ ) was placed in a $100 \mathrm{~m} l$ three-neck flask, provided with a mechanical stirrer and a gas-inlet tube. When dry $\mathrm{CO}_{2}$ was slowly introduced into the agitated DBU at room temperature, a white precipitate soon appeared. The precipitate was collected on a glass filter, washed with dry ether, and then dried in vacuo at room temperature. The material thus produced was confirmed by elementary analysis to be a DBU-CO $\mathrm{CO}_{2}$ adduct complex in $1: 1$ molar ratio. Found: C, 62.1; H, 7.9; N, 14.4\%. Calculated as $\mathrm{C}_{10} \mathrm{H}_{16} \mathrm{~N}_{2} \mathrm{O}_{2}: \mathrm{C}, 61.2 ; \mathrm{H}, 8.2 ; \mathrm{N}$, $14.2 \%$.

This paper was presented at the 20th meeting of The Japan Petroleum Institute at Osaka, November 9, 1977. 


\section{References}

1) Battaccio, G., Chiusoli, G. P.. Chem. Commun., 618 (1966).

2) Kwan, T., Yamamoto, H., Mori, H., Samejima, H., Kagaku Kogyo, 74, 1618 (1972).

3) Kudo, K., Takezaki, Y., Kogyo Kagaku Zasshi, 70, 2147 (1967).

4) Battaccio, G., Chiusoli, G. P., Felicioli, M. G., Gazz. Chim. Ital., 103, 105 (1973).

5) Mori, H., Yamamoto, H., Kwan, T., Chem. Pharm.
Bull., 20, 2440 (1972).

6) Hirao, I., Kito, T., Funamoto, T., Murakami, T., Usami, K., Bull. Chem. Soc. Jpn., 49, 2775 (1976).

7) Battaccio, G., Chiusoli, G. P., Felicioli, M. G., Tosi, E., Gazz. Chim. Ital., 106, 831 (1976).

8) Haruki, E., Arakawa, M., Matsumura, N., Otosuji, Y., Imoto, E., Chem. Lett., 427 (1974).

9) Hales, J. L., Jones, J. I., Lindsey, A. S., J. Chem. Soc., 3145 (1954).

10) Hirao, I., Kito, T., Bull. Chem. Soc. Jpn., 46, 3470 (1973).

要 旨

\title{
1,8-ジアザビシクロ $[5,4,0]$ ウンデ-7-エン $(\mathrm{DBU})$ 存在下でのシクロヘキノンの 二酸化岸素による炭酸化反応の速度論的研究
}

\author{
岩谷 全啓*, 工藤 清*, 杉田 信之*, 竹崎 嘉真*
}

活性メチレン化合物と二酸化炭素 $\left(\mathrm{CO}_{2}\right)$ とからのカルボン 酸合成に関しては多くの研究がなされており，特にアルカリ金 属フェノラートを用いた反応についてはその機構的研究が詳細 になされている(1),2),4),7)。最近，有機塭基で強い塩基性をもつ DBU が有效なカルボキシル化剂であることが春木ら8)によ一 て報告された。しかしその反応機構は明らかにされていない。 本報では活性メチレン化合物の一つとしてシクロヘキサノン （1）を選び，DMSO 溶液中 DBU の存在下で加压 $\mathrm{CO}_{2}$ によ る炭酸化反応，すなわちシクロヘキサノン-2-カルボン酸 (2) の生成反応について速度論的ならびに平衡論的研究を行った結 果について述べる。

予備実験の結果 (Table 1), 2 の生成する最適条件は温度 $60^{\circ} \mathrm{C}$ 付近であり，それ以上では $\mathrm{CO}_{2}$ 圧を上げても収率は減少 してくる。収量はほぼ 3 時間で頭打ちとなりそれ以上長時間継 続しても収率は上がらなく一定值を示し (Figs. 2, 3), しかも未 反応相当量の原料1が残っている。また長時間反応後の系に新 たに 1 を追加し同条件下で反応を継続することにより 2 の生成 量が増加してくる。これらの結果から本反応は平衡反応である と推察でき，高収率を得るためには低温高圧下で行うのが望ま しい。以下の速度論的検討は組成变化量を定量的に実測可能な 条件として $25^{\circ} \mathrm{C}$ 前後, $1 \sim 3$ 気圧の範囲で反応速度におよぼす DBU および1の充てえ初濃度， $\mathrm{CO}_{2}$ 圧および温度の影響につ いて反応律速条件で検討した（例として Figs. 2, 3)。温度に

* 京都大学化学研究所 (611 宇治市五ヶ庄)
関しては高くなる程速度は増しているが頭打ち収量は減少して くる。 $\mathrm{CO}_{2}, 1$ 执よび BDU についてはその圧力, 濃度の増加 につれて速度と頭打ち収量が増している。DBU は室温で乾燥 $\mathrm{CO}_{2}$ を常压下で作用させると容易に白色固体が析出してくる。 この白色固体は元素分析および IR 測定結果より $\mathrm{DBU}$ と $\mathrm{CO}_{2}$ が 1：1 からなる複合体であることがわかった。またこの白色 固体をDMSO 溶液中で 1 と反応させると 2 が生成してくる。 以上の結果などを考虑し，まず本反応を平衡反応 (Eq. 4) と 考え平衡定数 $\left(K^{\prime}\right)$ を求め (Eq. 5 より) Table 3 に示した。 $K^{\prime}$ の温度係数より求められた (Fig. 5) 見かけの反応熱は 10 $\mathrm{kcal} / \mathrm{mol}$ (発熱) である。次に反応機構を Eq. 6 (平衡), Eq. 7 (律速) からなると仮定し速度式を導くと Eq. 16 を得る。 この Eq. 16 を用い実験值を検討した結果, Figs. 6,7 に示す ように DBU, 1 の濃度, $\mathrm{CO}_{2}$ 压および温度の影響について時 間 $t$ と対数項との間にいずれの場合も直線関係が成立し Eq. 16 は実駼結果を満足している。したがって上記の反応機構 (Eq. $6 ， 7)$ は本反応を合理的に説明し得ると考える。ここで $R$ の式 (Eq. 14) を変形すると Eq. 17 となり, これより $1 / R$ と $1 / P$ との間に直線関係が得られ (Fig. 8) この傾きと切片とから $k_{2}$, $K_{1}$ を，また $K^{\prime}=k_{2} K_{1} / k_{-2}$ の関係から $k_{-2}$ のそれぞれの值を 求め Table 5 に示した。本反応の活性化エネルギーは（Fig. 9 より） $22 \mathrm{kcal} / \mathrm{mol}$ および複合体生成反応熱として $4 \mathrm{kcal} / \mathrm{mol}$ (発熱)を得た。

\section{Keyword}

Carbon dioxide, Carboxylation, Cyclohexanone, Cyclohexanone-2-carboxylic acid, 1, 8-Diazabicyclo [5, 4, 0] undec-7-ene, Kinetics 